\title{
Fatty filum with different histological features. Case report
}

\author{
Y. Izci; S. Pusat and O. Onguru* \\ Departments of Neurosurgery and Pathology*. Gulhane Military Medical Academy. Turkey.
}

\section{Summary}

Split cord malformation and fatty filum are completely different clinical entities and thought to arise via different pathophysiologies. Recognition of these distinct lesions in the same patient is important for appropriate diagnosis and management.

A 3 year-old boy presented with skin lesions and mild leg weakness suggestive of spinal malformation. Magnetic resonance imaging revealed type II split cord malformation at T12-L1, syringomyelia at T8-T10 levels associated with tethered cord and fatty filum terminale. The patient underwent a T12-L1 laminotomy for the removal of fibrous band between the 2 hemicords and L4-L5 laminotomy for transection of the fatty filum. Histopathological examination of the filum confirmed the presence of bone, fat, and ciliated epithelial cells associated with meningothelial proliferation in the same specimen.

We report an unusual case of type II split cord malformation coexisting with a fatty filum which have different histological patterns. To the best of our knowledge, this histological appearance of a fatty filum has not yet been reported and this raises the question of a possible associative or causative relationship between these distinct pathologies.

KEY WORDS. Split cord malformation. Fatty filum. Tethered cord. Child

Filum lipoatoso con características histológicas diferentes. Caso clínico

\section{Resumen}

La diastematomielia y el filum lipomatoso son entidades clínicas completamente diferentes y cuya patogenia se considera diferente. El reconocimiento de estas lesiones en el mismo paciente es importante para el diag-

Recibido: 12-06-10. Aceptado: 17-09-10 nóstico y manejo apropiados. Un niño de 3 años de edad se presentó con marcas cutáneas y moderada debilidad en piernas sugestivos de malformación espinal. La resonancia magnética reveló duplicación de la médula de tipo II y siringomielia T12-L1, que se asoció con anclaje medular y filum terminale lipomatoso. El paciente fue sometido a una laminotomía T12-L1 para la eliminación de la banda fibrosa entre las dos hemimédulas y laminotomía L4-L5 con sección del filum lipomatoso. EI estudio anatomopatológico del filum confirmó la presencia de hueso, grasa, y células epiteliales ciliadas, que se asociaron con proliferación meningotelial.

Informamos un caso excepcional de diastematomielia tipo II que coexiste con un filum lipomatoso con patrón histológico diferente. En nuestra opinion, este patrón histológico correspondiente al filum lipomatoso no ha sido documentado previamente, y ello suscita cuestiones sobre una posible relación, sea de asociación o cusal, entre estas dos patologías.

PALABRAS CLAVE. Diastematomielia. Filum lipomatoso. Anclaje medular. Niño.

Introduction

Split cord malformation (SCM) is a form of closed neural tube defect in which the spinal cord is longitudinally split by a fibrous band or a bone spicule. Type II SCM (Diplomyelia) consists of two hemicords housed in a single dural tube separated by a fibrous median septum². Patients with SCM may have multiple causes of tethering associated with their congenital anomaly such as myelomeningocele, intradural lipoma, and fatty filum ${ }^{2,8,9}$.

The fatty filum involves fatty infiltration of the whole length or of part of the filum terminale. It is the simplest form of conditions causing tethered cord syndrome (TCS) and the filum terminale can be thickened, normally with lipomatous tissue ${ }^{1,3}$. The fatty filum may be associated with $\mathrm{SCM}$, suggesting a common timing of pathogenesis during development.

A rare case of diplomyelia associated with a fatty filum 
Figure 1. (A) Preoperative sagittal T1-weighted MRI of the patient showing syringomyelia at T8-T10 level and conus ending at L4.

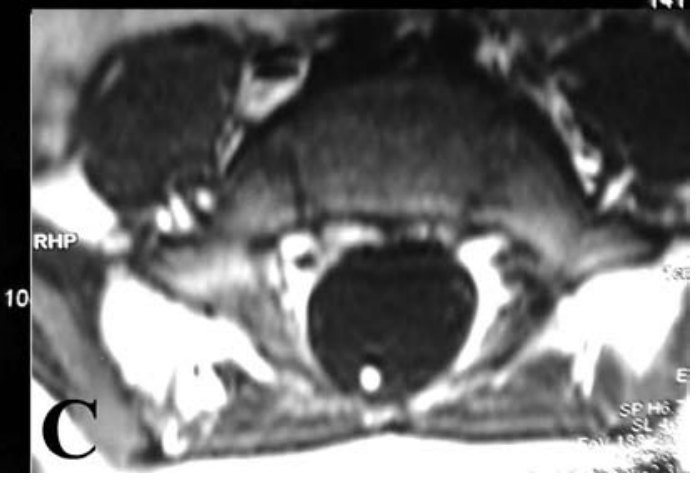
The white arrow shows the hyperintense fatty filum. (B) Axial T2weighted MRI section shows 2 hemicords that are separated by a thin fibrous band at T12 level. (C) The filum is hyperintense in axial MRI sections.

is presented. Bone, fat, and meningoepithelial proliferation associated with ciliated epithelial cells were found in the histological examination of the filum. These histological findings and possible pathogenetic mechanisms are discussed.

\section{Case report}

A 3-year-old boy presented with mild leg weakness and cutaneous lesions on the back. Physical examination revealed a dimple, and red lesions with a hairy patch. The child had normal power in his lower limbs. Both knee and ankle reflexes were present. He had a normal anal reflex. Spinal magnetic resonance (MR) images revealed a syringomyelia at T10-T12, a fibrous band dividing the spinal cord at T12 level and a low-lying conus with tethering of the cord at L5-S1, associated with the presence of fatty tissue at the lower end of the terminal filum (Fig. 1). Results of electrophysiological and urodynamic studies were normal.

The child underwent surgical exploration. The fibrous band between the 2 hemicords was removed via a T12-L1 laminotomy and the conus medullaris was released by cutting the fatty filum terminale via an L4-L5 laminotomy (Fig. 2). A part of the fatty filum was resected with preser- vation of the underlying neural structures.

The histological examination of the removed specimen consisted of a non-encapsulated piece of fatty tissue measuring $1 \times 0.6 \times 0.6 \mathrm{~cm}$. The cut surface showed a soft yellow area. Pathological examination of the resected

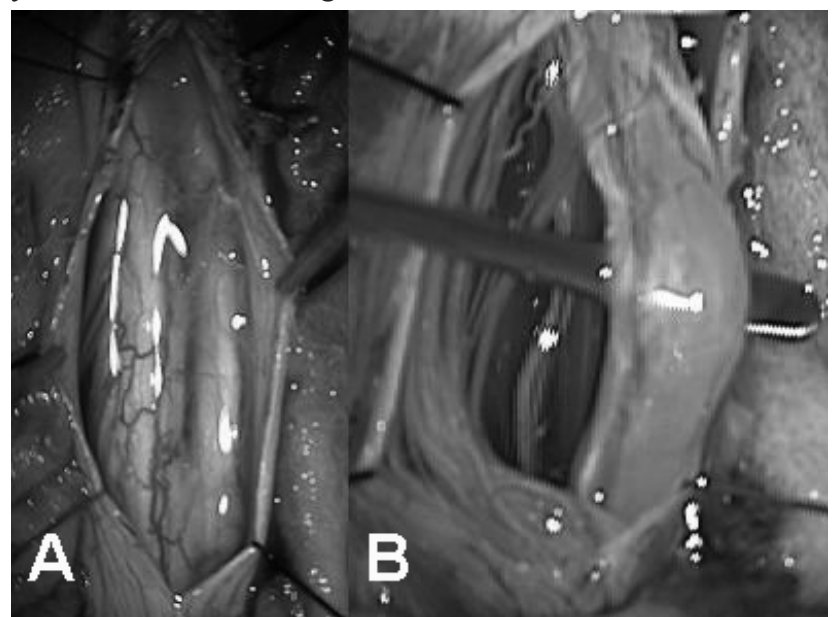

Figure 2. (A) Intraoperative view of the hemicords separated by a fibrous band at T12-L1 level; (B) Intraoperative view of the fatty filum at L5 level after laminotomies and dural openings. 


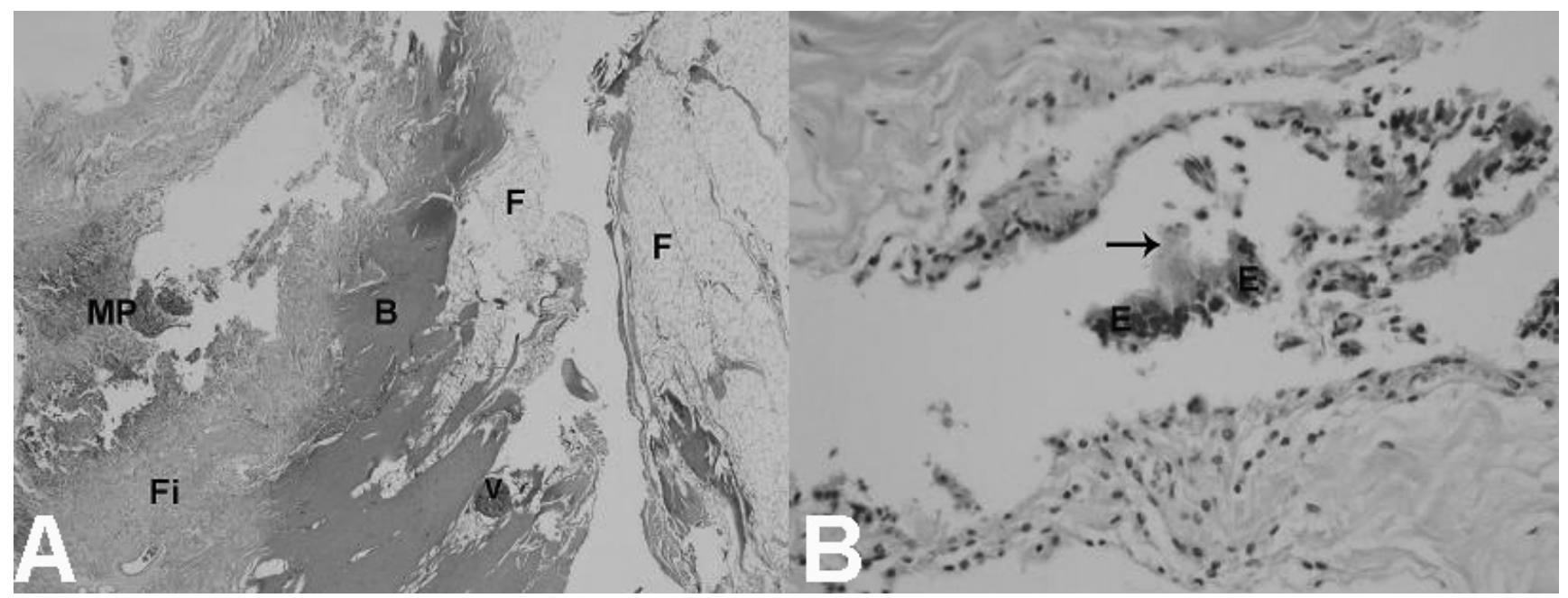

Figure 3. (A): histopathological examination of the filum shows bone and fat tissues associated with meningothelial proliferation and fibrous tissue. (B): bone, F: Fat, MP: Meningothelial proliferation, Fi: Fibrous tissue, V: Vessel (H\&E x40); (B) Ciliated epithelial cell bundles are obvious in the filum after magnification. The black arrow shows the cilia of the epithelial cells. E: Epithelial cell tuft (H\&Ex200).

tissue demonstrated an area with different cytoarchitecture. There was a complex cellular arrangement with sheets of meningothelial proliferation, bone, fat tissue and fibrosis. In some areas there were ciliated epithelial cells (Fig. 3). Postoperatively the patient began, mobilization and was discharged without any complication.

\section{Discussion}

Diplomyelia and fatty filum terminale are separate conditions presumed to have different underlying pathophysiological characteristics. Although fatty filum is a well-known coexisting pathology within the split cord malformations, this intriguing association with different histological patterns has not been previously reported in the pediatric literature.

The unified theory proposes that all SCMs originate from one basic ontogenetic error occurring around the time when the primitive neurenteric canal closes ${ }^{5}$. This basic error is the formation of an "accessory neurenteric canal" through the midline embryonic disc that maintains communication between yolk sac and amnion and enables continued contact between ectoderm and endoderm within the canal. Thus, according to the unified theory, both Type I and II SCMs originate from the same basic embryogenetic mechanism, the only difference between them being the presence or absence of meninx precursor cells in the endomesenchymal tract ${ }^{14}$. SCMs are usually associated with other pathologies such as $\mathrm{TCS}^{13,17}$, and the fatty filum is considered as one of the causes of this syndrome. In our case, we found Type II SCM associated with a TCS and fatty filum. But the histological characteristics of the filum were completely different to those of the normal filum.

Atrophy of the caudal neural tube is responsible for the formation of the filum terminale, which connects the future conus medullaris with the coccygeal medullary vestige, a mixed tissue containing ependymal cells, neurons, and glial cells embedded in fibrofatty fibrolipomatous tissue in the central area between the coccyx and the end of the dural sac. A fatty filum seems to occur due to a congenital error in the canalization of the caudal bud of the spinal cord. An aberrant accumulation of mesenchymal precursor cells from the pluripotent cell mass of the caudal eminence is thought to lead to an abnormal retrogressive differentiation of the secondary neural cord ${ }^{10,12,15}$. The exact mechanism is not well understood, but one could propose that faulty cell movements may prevent the migration of the mesodermal cells to their normal positions, subsequently leading to distal cord dysfunction. These changes may cause the formation of adhesions of the fatty filum to the adjacent structures and the traction effect on the spinal cord without by preventing the normal flexibility and elasticity thus predisposing to cord tethering ${ }^{10}$.

Although it has been reported that a filum terminale that is either fatty or thick might have a tethering effect on the spinal cord, which causes symptoms of tight spinal cord syndrome, it has also been reported that a normal thickness filum terminale can have a tethering effect if its natural architecture is changed due to various factors. In general, the diagnosis of TCS is based on clinical findings and serial neurological examinations, with radiological investigations playing a secondary role. The fat within the short, thick filum is discernible by unenhanced computed tomography or MR imaging ${ }^{4}$. MR is excellent for detecting 
diplomyelia and for showing hyperintense fat within the thickened filum. The demonstration of this fat is diagnostic of an abnormal filum terminale. We detected diplomyelia and fatty filum on the preoperative MR imaging and planned surgery in the light of these findings. We also obtained filum samples for histopathological examination.

The normal filum is composed largely by loose collagen fibers, but it also contains small blood vessels and occasional small nerve fascicles ${ }^{18}$. In addition, remnants of the central canal lined with ependymal cells may also be detected in some specimens ${ }^{6,7,11}$. But in a thickened filum, elevated numbers of collagen bundles, scattered nests of ependymal cells, glial cells, large clumps of fat cells, and areas of hyalinization are frequently observed throughout the connective tissue. Ciliated epithelial cells, meningothelial proliferation and bone tissue are not frequently found in a thickened filum. Our case emphasizes the need to obtain a full histopathological examination of the tissues resected during surgery for TCS with fatty filum. Early detection of the associated lesions may alter the long-term prognosis in these patients by using with the appropriate treatment and follow-up with sequential MR imaging studies.

In conclusion, TCS must be evaluated carefully with appropriate radiological techniques. Structure of the spinal cord and the morphology of the filum terminale should be examined in detail and histopathological assessment of the filum after the surgery should be kept in mind for differential diagnosis.

\section{References}

1. Adamson, D.C., Cummings, T.J., Friedman, A.H.: Myxopapillary ependymoma and fatty filum in an adult with tethered cord syndrome: a shared embryological lesion? Case report. Neurosurgery 2005; 57: E373.

2. Akay, K.M., Izci, Y., Baysefer, A., Timurkaynak, E.: Split cord malformation in adults. Neurosurg Rev 2004; 27 : 99-105.

3. Bui, C.J., Tubbs, R.S., Oakes, W.J.: Tethered cord syndrome in children: a review. Neurosurg Focus 2007; 23: 1-9.

4. Bulsara, K.R., Zomorodi, A.R., Enterline, D.S., George, T.M.: The value of magnetic resonance imaging in the evaluation of fatty filum terminale. Neurosurgery 2004; 54 : 375379.

5. Erşahin, Y., Mutluer, S., Kocaman, S., Demirtaş, E.: Split spinal cord malformations in children. J Neurosurg 1998; 88: 57-65.
6. Fontes, R.B., Saad, F., Soares, M.S., de Oliveira, F., Pinto, F.C., Liberti, E.A.: Ultrastructural study of the filum terminale and its elastic fibers. Neurosurgery 2006; 58: 978984.

7. Gamble, H.J.: Electron microscope observations upon the conus medullaris and filum terminale of human fetuses. $\mathrm{J}$ Anat 1971; 110: 173-179.

8. Izci, Y., Gurkanlar, D., Gönül, E.: An unusual type of split cord malformation. J Clin Neurosci 2007; 14: 383-386.

9. Izci, Y., Gonul, M., Gonul, E.: The diagnostic value of skin lesions in split cord malformations. J Clin Neurosci 2007; 14: 860-863.

10. Karabatsou, K., Crooks, D., Williams, D., Buxton, N.: Combination of myxopapillary ependymoma and fatty filum in a child with tethered cord syndrome. Case report. J Neurosurg Pediatr 2008; 1: 386-388.

11. Miller, C.: The ultrastructure of the conus medullaris and filum terminale. J Comp Neurol 1968; 132: 547-566.

12. Muthukumar, N., Srisaravanan, J.: Intramedullary dermoid in a low lying conus tethered by a fatty filum - embryological implications. Acta Neurochir (Wien) 2007; 149: 1173-1175.

13. Ozturk, E., Sonmez, G., Mutlu, H., et al.: Split cord malformation and accompanying anomalies. J Neuroradiol 2008; 35: 150-156.

14. Pang, D., Dias, M.S., Ahab-Barmada, M.: Split cord malformation: Part I: A unified theory of embryogenesis for double spinal cord malformations. Neurosurgery 1992; 31: 451-480.

15. Pinto, F.C., Fontes, R.B., Leonhardt, Mde C., Amodio, D.T., Porro, F.F., Machado, J.: Anatomic study of the filum terminale and its correlations with the tethered cord syndrome. Neurosurgery 2002; 51: 725-729.

16. Samuels, R., McGirt, M.J., Attenello, F.J., et al.: Incidence of symptomatic retethering after surgical management of pediatric tethered cord syndrome with or without duraplasty. Childs Nerv Syst 2009; 25: 1085-1089.

17. Schijman, E.: Split spinal cord malformations: report of 22 cases and review of the literature. Childs Nerv Syst 2003; 19: 96-103.

18. Selçuki, M., Vatansever, S., Inan, S., Erdemli, E., Baðdatoðlu, C., Polat, A.: Is a filum terminale with a normal appearance really normal? Childs Nerv Syst 2003: 19: 3-10.

Izci, Y.; Pusat, S.; Onguru, O.: Fatty filum with different histological features. Case report. Neurocirugia 2010; 21 : 457-460. 